$\begin{array}{r}\text { Bartın Üniversitesi } \\ \text { Eğitim Fakültesi Dergisi }\end{array}$
Cilt 5, Sayı 3, s. 690-717, Ekim 2016
BARTIN - TÜRKIYE $\begin{aligned} & \text { Bartin University } \\ & \text { Journal of Faculty of Education } \\ & \text { Volume 5, Issue 3, p. 690-717, 0ctober } 2016 \\ & \text { BARTIN - TURKEY }\end{aligned}$

Doi: 10.14686/buefad.v5i3.5000195158

\title{
Ortaokul Öğrencilerinin Etkileşimli Tahta Kullanımına Yönelik Tutumlarının Farklı Değişkenler Açısından İncelenmesi
}

\author{
Agâh Tuğrul KORUCU, Yrd. Doç. Dr., Necmettin Erbakan Üniversitesi, Ahmet Keleşoğlu Eğitim Fakültesi, Bilgisayar ve \\ Öğretim Teknolojileri Eğitimi Anabilim Dalı, akorucu@konya.edu.tr \\ Ertuğrul USTA, Doç. Dr., Necmettin Erbakan Üniversitesi, Ahmet Keleşoğlu Eğitim Fakültesi, Bilgisayar ve Öğretim Teknolojileri \\ Eğitimi Anabilim Dalı, ertugrulusta@gmail.com \\ Lale TORAMAN, Yüksek lisans öğrencisi, Necmettin Erbakan Üniversitesi, Ahmet Keleşoğlu Eğitim Fakültesi, Bilgisayar ve \\ Öğretim Teknolojileri Eğitimi Anabilim Dalı, laletoraman.t@gmail.com
}

Öz: Eğitim ve öğretimde teknolojinin kullanılması öğrencilerin derse katılmada heyecanlı ve istekli olmalarını sağladığı, ayrıca motivasyonu arttırmada, öğrencileri derse teşvik etmede ve konuyu anlamada daha etkili bir araç olduğu vurgulanmaktadır. Eğitim ve öğretimde kullanılan teknolojilerden bir tanesi de Etkileşimli tahtalardır. Etkileşimli tahtanın belirtilen bu özellikleri ve Fatih Projesi ile amaçlanan eğitimde fırsat eşitliği, teknolojiyi iyileştirme hareketinin öğrenciler tarafından ne şekilde kabul edildiği önemlidir. Buradan hareketle, bu çalışmanın amacı etkileşimli tahtanın eğitimde kullanılmasına yönelik ortaokul öğrencilerinin görüşlerinin incelenmesidir. Bu çalışmada araştırma modeli olarak karma (mixed) yöntem olarak kullanılan hem nicel hem de nitel araştırma yöntemi kullanılmıştır. Veri toplama aracı olarak araştırmacılar tarafından geliştirilen ve çalışma grubu öğrencilerinin demografik verilerinin elde edildiği kişisel bilgi formu ile Yarı yapılandırılmış formdaki 6 adet açık uçlu soru ve Çelik ve Atak (2012) tarafından geliştirilen "Etkileşimli Tahta Tutum Ölçeği (ETTÖ)" kullanılııştır. Nicel verilerin çözümlenmesinde istatistik bilgisayar paket programı ve nitel verilerin çözümlenmesinde içerik analizi tekniği kullanılmıştır. Araştırma sonucunda ortaokul öğrencilerinin etkileşimli tahtaya yönelik tutumlarının cinsiyet durumlarına, tablet bilgisayar sahip olmalarına, haftalık internet kullanım sürelerine ve mobil cihaz sahip olma sürelerine göre değişmediği, ancak öğrenim gördükleri sınıflara ve mobil cihaz kullanımı yeterlilik düzeylerine göre değiştiği sonuçlarına ulaşılmıştır.

Anahtar Kelimeler: Etkileşimli Tahta, Bilgi Ve İletişim Teknolojileri, Ortaokul Öğrencisi

\section{The Examining of Secondary School Students' Attitudes about Interactive Smart Board Using}

Abstract: It is emphasized that, in education and teaching, using technology make student excited and willing in participating lesson, and it is more effective tool in encouraging student to lesson and understand the topic. One of the technologies which used in education is smart board. It is important how the students' admitting these smart boards' features, equality of opportunity which is aimed with FATIH project, and improving technology movement. So, this work's purpose is to examine secondary school students' views about using interactive boards in education.--In this work quantitative and qualitative research methods- was used. As getting data tool; personal information form which is developed by researchers and obtained research group students' demographic data and 6 open - ended question in semi-structured form and interactive board attitude scale which was developed by Çelik and Atak (2012) were used. In the analysis of quantitative data, statistical software packages and in the analysis of qualitative data, content analysis technique was used. In the result it is reached that secondary school students' attitudes about interactive board doesn't change according to their gender status, having tablet, weekly internet using but change according to class which in studying, mobile device usage levels of proficiency.

Key Words: Interactive Board, Information And Communication Technology, Secondary School 


\section{GíRiş}

Geçmişten günümüze insan ihtiyaçlarına göre sürekli gelişim ve değişimler meydana gelmiştir. Bu gelişmeler sonucunda toplumlar da farklı gelişme aşamaları geçirmiştir. Bu gelişme aşamalarına göre toplumlar ilkel toplum, tarım toplumu, sanayi toplumu ve günümüzde de bilgi toplumu olarak isimlendirilmektedir. Bilgi toplumu, 1950 - 1960 yıllarında bilgi teknolojilerinin gelişmiş ülkelerde giderek artan bir şekilde kullanılmasıyla ortaya çıkmıştır (Alkan ve Tunç, 1998). 21. Yüzyılda gelişen teknolojiler bilgiye ulaşmayı, paylaşmayı ve etkin kullanmayı sağlamaktadır ve bireylerinden beklenen özellikler de değişmiştir. Bilgi toplumunda insanların sürekli gelişen, değişen ve artan bilgileri ezberlemesi olanaksız hale gelmiştir. Bunun yerine bilgiye nasıl ulaşabileceğini bilen, gerektiği yerde bilgilerini kullanabilen, yeni bilgiler üretebilen bireyler olması beklenmektedir (Çepni, 2005; Akt. Çelik ve Kahyaoğlu, 2007). Bilgi ve teknolojinin yoğun olarak kullanıldığı bilgi toplumunda insanların sahip olması gereken özellikler; bilgiye ulaşma, paylaşma, düzenleme ve değerlendirme, ayrıca bilgiyi sunma ve iletişim kurma becerilerine sahip olma şeklinde belirtilmiştir (Akkoyunlu, 1995; Akt. Temelli ve Genç, 2014). Teknolojideki gelişmeler her alanı olduğu gibi eğitim-öğretim alanını da etkilemektedir (Kanatlı ve SchregIman, 2012). Bilgi ve iletişim teknolojilerinde gelişimle eğitim ve öğretimde yeni yöntem ve araçların eğitimde kullanılmasını da mümkün olmuş, -bilgi ve iletişim teknolojilerinin eğitime entegrasyonu, çokluortam, ses, görüntü, animasyon, internet ve gelişen internet teknolojileri eğitim-öğretimde kullanılmaya başlanmıştır (Alakoç, 2003; Akt. Türkoğlu, 2004). Bilgi teknolojilerinin eğitim ortamlarında kullanımı eğitim teknolojisini ortaya çıkarmaktadır (Erduran ve Tataroğlu, 2010). Eğitim teknolojisi; eğitimi geliştirmek, iyileştirmek, eğitimde kaliteyi artırmak olarak tanımlanmaktadır (Seyitoğlu, 2014). Eğitim teknolojisinin kapsadığı terimler; çalışma, etik kurallar, öğretimi kolaylaştırma, öğrenme, geliştirme, performans, yenilikçilik, teknolojiyi kullanma, teknolojiyi yönetme, teknoloji uygunluğu, süreç ve kaynaklardır (AECT, 2004). Eğitimde teknoloji kullanımının birçok yararı vardır. Bazıları şu şekilde belirtilmiştir (Akkoyunlu, 1998: 4): Eğitimde teknoloji kullanımı; öğrenmenin niteliğini arttırır, öğrencilerin ve öğretmenlerin hedefe ulaşmak için harcadıkları zamanı azaltır, öğretmenin etkinliğini arttırır, niteliği düşürmeden eğitimin maliyetini düşürür, öğrenciyi ortamda etkin kılar.

Bilgi ve iletişim teknolojilerinin her alanda kullanılması, yeni nesillere bilgi ve iletişim teknolojilerini kullanma becerilerinin kazandırılmasının önemini göstermektedir (Kılınç, 2015). Ülkemizde de teknoloji ile sağlanacak olumlu öğretim ortamları oluşturmak ve öğrenci başarısını artırmak için gelişen teknolojinin eğitimde kullanımıyla ilgili çeşitli projeler yürütülmektedir. Bunlardan biri de Kasım 2010'da ilan edilen ve Milli Eğitim Bakanlığı ve Ulaştırma Bakanlığı'nın işbirliği ile yürütülen, Fırsatları Artırma ve Teknolojiyi İyileştirme Hareketi isimli ve kısaca FATiH olarak bilinen projedir. Bu proje kapsamında pek çok okulda Etkileşimli tahta, internet, ağ bağlantısı gibi teknolojik altyapı sağlanmakta ve öğrencilere tablet dağıtılarak eğitimde kalitenin artırılması hedeflenmektedir (Gündüz ve Çelik, 2015). Proje ilköğretim ve ortaöğretim düzeyindeki okullara toplam 570.000 adet etkileşimli tahta, öğrencilere 11.136.752, öğretmenlere 715.000 adet tablet bilgisayar ve 620.000 adet sınıfa internet ağ altyapısı sağlanmasını öngörmektedir (Milli Eğitim Bakanlığı [MEB], 2012). Etkileşimli tahta kullanımı öğrencilerin problem çözme, yaratıcılık ve birbirleriyle işbirliği içinde olma gibi yeteneklerini geliştirmeye yardımcı olur (Oleksiw, 2007). Etkileşimli tahta; kavramları görselleştirme, bütünlük ve kalıcılık sağlama, öğrenmeye teşvik etme, motivasyon ve etkililik sağlama, çok yönlü ve kolay kullanım, karşılıklı etkileşim gibi özelliklere sahip olmasından dolayı eğitim ortamında kullanılması öğrenme-öğretme sürecine katkı sağlamaktadır ve eğitim ortamlarında kullanılabilecek en etkili teknolojilerden biridir- (Painter, Whiting, Wolters ve Park, 2005). Etkileşimli tahta büyük grupların gösterilen sunuyu görmesine ve dokunmasına olanak sağladığı, tahtanın üzerinde uygulamalar yapmak etkileyici ve yaratıcı öğrenme 
deneyimleri kazandırdığı için Etkileşimli tahtayı kullanarak bilgiyi sunmak daha kolay ve etkilidir (Roennigke ve Carter, 2001). Etkileşimli tahta, öğrencilerin derse katılmada heyecanlı ve hevesli olmalarını sağlamıştır ve Etkileşimli tahtanın motivasyonu arttırmada, derse teşvik etmede ve konuyu anlamada etkili bir araç olduğu belirtilmiştir (Oleksiw, 2007).

Wall, Higgins ve Smith (2005) çalışmalarında öğrencilerin çoğunun Etkileşimli tahtaları farklı nedenlerle olumlu algıladıklarını belirtmişlerdir. Etkileşimli tahta ve etkin öğrenci katılımı sayesinde öğrenme sürecinin başlatılması ve kolaylaştırılmasının sağlandığı ortaya çıkarılmıştır. Robinson (2004) araştırmasının sonucunda Etkileşimli tahta kullanımının öğrencilerin etkileşimini ve derse gönüllü olarak katılımlarını artırdığını tespit etmiştir. Etkileşimli tahtanın öğrencilere eleştirel düşünme ve tahmin yapmada güven sağladığı belirlenmiştir. Clemens, Moore ve Nelson (2001) yaptıkları çalışmada Etkileşimli tahta kullanımının akademik başarıyı arttırdığı, öğrencilerin eğitimde teknoloji kullanımına karşı tutumlarını olumlu yönde etkilediği, motivasyonlarını, derse karşı heveslerini artırdığı ve öğrenmelerini kolaylaştırdığı sonucuna ulaşmışlardır. Winkler (2011) Etkileşimli tahta eğitimi yapılan sınıfta öğretmen performansı ve öğrenci başarısının arttığı görülmüştür. Morgan (2008) çalışmasında Etkileşimli tahta kullanılan ve kullanılmayan eğitim arasında öğrenci davranışlarında önemli farklılıklar olduğu sonucuna ulaşmıştır. Etkileşimli tahta kullanımının öğrencilerin derslerinde olumlu etkiler sağladığı ve öğrenci davranışlarını geliştirmeye yardımcı olduğu görülmüştür. Yıldızhan (2013) çalışmasında Etkileşimli tahtanın öğrenci motivasyonunu ve derse katıımını arttırdığını belirtmiştir.

Bu bağlamda Etkileşimli tahtanın belirtilen özellikleri ve Fatih Projesi ile amaçlanan eğitimde fırsat eşitliği, teknolojiyi iyileştirme hareketinin öğrenciler tarafından ne şekilde kabul edildiği önemlidir. Dolaysıyla, bu çalışmanın amacı etkileşimli tahtanın eğitimde kullanılmasına yönelik öğrencilerin görüşlerinin incelenmesidir. Buradan hareketle bu araştırmayı yönlendiren araştırma soruları şunlardır;

1- Ortaokul öğrencilerinin etkileşimli tahta tutum ölçeğinden aldıkları puanlar cinsiyet değişkenine göre anlamlı bir farklılık göstermekte midir?

2- Ortaokul öğrencilerinin etkileşimli tahta tutum ölçeğinden aldıkları puanlar öğrenim gördükleri sınıflara göre anlamlı bir farklılık göstermekte midir?

3- Ortaokul öğrencilerinin etkileşimli tahta tutum ölçeğinden aldıkları puanlar tablet bilgisayar sahip olmalarına göre anlamlı bir farklılık göstermekte midir?

4- Ortaokul öğrencilerinin etkileşimli tahta tutum ölçeğinden aldıkları puanlar haftalık internet kullanım sürelerine göre anlamlı bir farklılık göstermekte midir?

5- Ortaokul öğrencilerinin etkileşimli tahta tutum ölçeğinden aldıkları puanlar mobil cihaz sahip olma sürelerine göre anlamlı bir farklılık göstermekte midir?

6- Ortaokul öğrencilerinin etkileşimli tahta tutum ölçeğinden aldıkları puanlar mobil cihaz kullanımı yeterlilik düzeylerine göre anlamlı bir farklılık göstermekte midir?

\section{YÖNTEM}

\section{1. Çalışma Grubu}

Araştırmanın çalışma grubunu Konya ilinde eğitim-öğretime devam eden bir devlet ortaokulunda öğrenim gören 225 ortaokul öğrencisi [113 (\% 50,2)'si kız, 112 (\% 49,8)'i erkektir] oluşturmaktadır.

\section{2. İşlem}

Bu çalışmada araştırma modeli olarak karma (mixed) yöntem olarak kullanılan hem nicel hem de nitel araştırma yöntemi kullanılmıştır. Araştırmanın nitel kısmında öğrenci görüşleri, geliştirilen yarı yapılandırılmış formdaki açık uçlu sorularla toparlanmıştır. Araştırma problemlerinin daha ileri bir düzeyde anlaşıımasında nicel ve nitel araştırma yöntemleri ile 
karma yöntemde çeşitli verilerin toplanması büyük fayda sağlamaktadır. Araştırmanın nicel kısmında tarama modeli kullanılmıştır. Karma yöntem olarak adlandırılan bu yöntemde amaç, tek bir araştırma içerisinde nicel ve nitel yöntemlerin karıştırılarak bu şekilde toplanan verilerin analizlerinin araştırma problemlerinin çözümüne odaklanmasını sağlamaktır.

Burada nitel araştırmanın amacı, araştırılan konuyu detaylıca gerçekçi bir şekilde ortaya koymaktır. Dolayısıyla verilerin olabildiğince ayrıntılı, doğrudan ve mümkün olduğunca çalışma grubunun ifadeleriyle desteklenerek analiz edilmesi önemlidir, nicel araştırmanın amacı ise toplanan verilerin ileri sürülen teorinin uygunluğunu, öğrenme çıktılarına etkisini incelemektir (Creswell ve Plano-Clark, 2007; Miles ve Huberman 1994; Straus ve Corbin, 1998). Nitel durum çalışmalarının en temel özelliği bir ya da birkaç durumun derinliğine araştırılmasıdır. Bir başka deyişle bir duruma ilişkin etkenler (ortam, öğrenciler, öğretmenler, olaylar, süreçler, vb.) bütüncül bir yaklaşımla araştırılır ve var olan durumu nasıl etkiledikleri ya da mevcut durumdan nasıl etkilendikleri üzerine derinlemesine bilgi kazandırır. Durum çalışması; "nası ?" ve "niçin ?" sorularını temel alarak araştırmacının kontrol edemediği bir olgu ya da olayı ayrıntılı bir şekilde derinlemesine incelemesine olanak sağlayan bir araştırma yöntemidir (Yıldırım ve Şimşek, 2008).

Veri toplama aracı olarak araştırmacılar tarafından geliştirilen ve çalışma grubu öğrencilerinin demografik verilerinin elde edildiği kişisel bilgi formu ve Çelik ve Atak (2012) tarafından geliştirilen "Etkileşimli Tahta Tutum Ölçeği (ETTÖ)" kullanılmıştır. ETTÖ, 5'li likert tipte olup 18 madde olumlu, 6 madde olumsuz toplamda 24 maddeden ve 3 alt boyuttan oluşmaktadır. Ölçek seçenekleri "Hiç Katılmıyorum", "Katılmıyorum", "Kararsızım", "Katılıyorum", "Tamamen Katılıyorum" sırası ile yer almaktadır. Ölçekteki 3 faktörün adları; illk faktör etkileşimli tahtanın kolaylıklarına ilişkin maddeleri içerdiği için "Etkileşimli tahtanın Kolaylıkları (1-11 arası maddeler)" olarak, ikinci faktör etkileşimli tahtanın zorluklarına ilişkin maddeleri içerdiği için "Etkileşimli tahtanın Zorlukları (12-20 arası maddeler)" olarak ve son faktör öğretmenin etkileşimli tahta kullanımına ilişkin maddeleri içerdiği için "Öğretmenin Etkileşimli tahta Kullanımı (21-24 arası maddeler)" olarak belirlenmiştir. Ölçeğin doğrulayıcı faktör analizi sonuçları; X²/sd: 2,01; GFI .94, AGFI .92, CFI .95, NFI .91, NNFI .95; RMR .06 ve RMSEA.06 olarak belirlenmiştir ve ölçeğin iyilik uyum indekslerinin varsayılan değerler ile uyumlu olduğunu göstermektedir. Ölçeğin Cronbach Alfa güvenirlik katsayısı Etkileşimli Tahtanın Kolaylıkları alt boyutu için 0.92, Etkileşimli Tahtanın Zorlukları alt boyutu için 0.91, Öğretmenin Etkileşimli Tahta Kullanımı alt boyutu için 0.90 ve son olarak ölçeğin tamamı için 0.83 olarak belirlenmiştir. Ayrıca nitel verilerin toplanması için araştırmacılar tarafından geliştirilen açık uçlu 7 araştırma sorusu yapılandırı Imış form haline getirilmiştir. 4 alan uzmanı ve 1 dil uzmanı, toplam 5 uzman kontrolünde revize edilen form açık uçlu 6 soru şeklinde son haline getirilmiştir. Yarı yapılandırılmış formdaki açık uçlu araştırma soruları şunlardır;

1. Derslerinizde Etkileşimli tahta kullanımı avantaj sağlamakta mıdır?

2. Derslerinizde Etkileşimli tahta kullanımı sizin derse karşı motivasyonunuzu ne yönde etkilemektedir?

3. Derslerinizde Etkileşimli tahta kullanımı sınıf ortamını ve etkileşimi ne yönde etkilemektedir?

4. Derslerinizde Etkileşimli tahta kullanımının en çok sevdiğiniz ya da sevmediğiniz yönü / yönleri ne olmuştur?

5. Derslerinizde Etkileşimli tahta kullanımının daha etkili hale getirilmesi için hangi önerilerde bulunursunuz?

6. Derslerinizde geleneksel yöntemler (Beyaz tahta kullanımı) ile Etkileşimli tahta kullanımı arasında bir kıyaslama yapsanız hangisini tercih edersiniz? Neden? 
Araştırma kapsamında elde edilen veriler SPSS (The Statistical Package for The Social Sciences) paket programı kullanılarak çözümlenmiş ve tüm hipotezler 0.95 güven düzeyinde ( $p$ $=0.05$ ) test edilmiştir. Araştırma kapsamında elde edilen veriler parametrik test varsayımlarını karşıladığından $(\mathrm{N}=225)$, verilerin çözümlenmesinde parametrik testlerden yararlanılmıştır. Bu bağlamda, her bir alt amaç için kullanılan testler aşağıda açıklanmıştır. Katılımcılardan toplanan demografik veriler betimsel istatistik yöntemlerinden frekanslar verilerek açıklanmıştır. Katılımcıların cinsiyetlerine ve tablet bilgisayar sahip olma durumlarına göre anlamlı bir farklılık gösterip göstermediğini test etmek için; ilişkisiz örneklemler için t-testi kullanılmıştır. Katılımcıların ölçekten aldıkları puanların; öğrenim gördükleri sınıflara, haftalık internet kullanım sürelerine, mobil cihaz kullanım yeterlilik düzeylerine göre, mobil teknolojilere sahip oldukları sürelere göre anlamlı bir farklılık gösterip göstermediğini test etmek için ise; ilişkisiz örneklemler için tek faktörlü varyans analizi (one-way anova) tekniğinden yararlanılmıştır.

Nicel araştırma ile elde edilen bulguları desteklemek amacıyla nitel araştırma yöntemlerinden yarı yapılandırılmış formda bulunan 6 adet açık uçlu soru uygulanmıştır. Veriler araştırmacılar tarafından önce bilgisayar ortamında yazılı hale getirilmiş sonra da nitel araştırma tekniklerden içerik analizi kullanılarak çözümlenmiştir. İçerik analizi (Silverman, 2001) çoğunlukla yazılı ve görsel verilerin analiz edilmesinde kullanılan bir yöntemdir. İçerik analizinde konuyla ilgili kategoriler belirlenerek metindeki incelenen veriler belirlenen kategorilere göre gruplandırılır (Özdemir, 2010, s. 335-336). Nitel araştırma verileri içerik analizi yöntemi ile verilerin kodlanması, temaların bulunması, kodların ve temaların düzenlenmesi, bulguların tanımlanması ve yorumlanması şeklinde dört aşamada analiz edilir (Yıldırım ve Şimşek, 2013). Çalışmanın bu bölümünde, çalışma grubundaki öğrencilerin görüşme sorularına verdiği cevaplar kodlanarak temalar elde edilmiştir. Daha sonra elde edilen veriler düzenlenerek benzerlikleri bakımından gruplandırılmış ve yorumlanmıştır. Ayrıca her soruya verilen bir ya da iki cevap da aynen sunulmuştur. Çalışma grubundaki öğrencilerin gerçek isimleri kullanılmamıştır. Bunun yerine her birine sırası ile Ö1, Ö2, Ö3... Ö30 şeklinde kodlamalar yapılmıştır. Araştırmada elde edilen bulgular görüşme formunda yer alan sorulara göre sıralanmıştır.

\section{BULGULAR}

\subsection{Araştırmanın Nicel Kısmına Ait Bulgular}

Araştırmaya katılan ortaokul öğrencilerinin demografik verilerinin verildiği bilgiler aşağıdaki Tablo1'de verilmiştir: 
Tablo 1

Çalışma Grubu Öğrencilerinin Demografik Verileri

\begin{tabular}{|c|c|c|c|}
\hline & & $\mathrm{N}$ & $\%$ \\
\hline \multirow{3}{*}{ Cinsiyet } & Kız & 113 & 50,2 \\
\hline & Erkek & 112 & 49,8 \\
\hline & Toplam & 225 & 100,0 \\
\hline \multirow{5}{*}{$\begin{array}{l}\text { Öğrenim gördüğü } \\
\text { sınıf düzeyi }\end{array}$} & 5.sınıf & 53 & 23,6 \\
\hline & 6.sınıf & 55 & 24,4 \\
\hline & 7.sınıf & 66 & 29,3 \\
\hline & 8.sinif & 51 & 22,7 \\
\hline & Toplam & 225 & 100,0 \\
\hline \multirow{6}{*}{ Yaş } & 10 & 18 & 8,0 \\
\hline & 11 & 60 & 26,7 \\
\hline & 12 & 52 & 23,1 \\
\hline & 13 & 70 & 31,1 \\
\hline & 14 & 25 & 11,1 \\
\hline & Toplam & 225 & 100,0 \\
\hline
\end{tabular}

Tablo 1'de görüldüğü gibi araştırmaya katılan 225 ortaokul öğrencisinden 113 (\% 50,2)'si kız, 112 (\% 49,8)'i erkektir. Öğrenim gördüğü sınıflara göre öğrencilerin dağılımları şu şekildedir; 5. Sınıfta 53 kişi (\% 23,6), 6. Sınıfta 55 kişi (\% 24,4); 7. Sınıfta 66 kişi (\% 29,3); 8. Sınıfta 51 kişi (\% $22,7)$ olarak belirlenmiştir. Ayrıca öğrencilerin yaş dağılımları şu şekildedir; 10 yaşında olan öğrenciler 18 kişi (\% 8); 11 yaşında olan öğrenciler 60 kişi $(\%$ 26,7); 12 yaşında olan öğrenciler 52 kişi (\% 23,1); 13 yaşında olan öğrenciler 70 kişi (\% 31,1); 14 yaşında olan öğrenciler 25 kişi (\% 11,1) olarak dağılım göstermiştir.

Birinci araştırma sorusuna yönelik bulgular (Ortaokul öğrencilerinin etkileşimli tahta tutum ölçeğinden aldıkları puanlar cinsiyet değişkenine göre anlamlı bir farklılık göstermekte midir?)

Ortaokul öğrencilerinin etkileşimli tahta tutum ölçeğinden aldıkları toplam puanları cinsiyet değişkenine göre anlamlı bir farklılık gösterip göstermediğine dair bulgular ilişkisiz örneklemler $\mathrm{t}$ - testi ile belirlenmiş ve Tablo 2 'de verilmiştir.

Tablo 2

Etkileşimli Tahta Tutum Ölçeği Puanlarının Cinsiyet Durumlarına Göre Sonuçları

\begin{tabular}{cllllll}
\hline Gruplar & $\mathbf{N}$ & $\bar{X}$ & $\mathbf{S}$ & $\mathbf{S d}$ & $\mathbf{T}$ & $\mathbf{p}$ \\
\hline Kız & 113 & 84,7168 & 12,19299 & 223 &,- 421 &, 674 \\
Erkek & 112 & 85,4911 & 15,25873 & & & \\
\hline
\end{tabular}

$* \mathrm{P}<0.05$

Tablo $2^{\prime}$ de de görüldüğü gibi ${ }^{*} p<.05$ anlamlılık düzeyi için $.674>.05$ olduğu için sonuç anlamlı değildir. Ortaokul öğrencilerinin etkileşimli tahta tutum ölçeğinden aldıkları toplam puanların ortalaması (erkeklerin ortalaması $\bar{X}=85,4911$; kızların ortalaması $\bar{X}=84,7168$ ) birbirine yakın çıkmıştır. Dolayısıyla Tablo 2'den de görüldüğü gibi ${ }^{*} p<.05$ anlamlılık düzeyi için $.674>.05$ 'dir ve sonuç anlamlı değildir. Bir başka deyişle ortaokul öğrencilerinin etkileşimli tahtaya yönelik tutumları cinsiyet durumlarına göre anlamlı bir farklııı göstermemektedir. 
İkinci araştırma sorusuna yönelik bulgular (Ortaokul öğrencilerinin etkileşimli tahta tutum ölçeğinden aldıkları puanlar öğrenim gördükleri sınıflara göre anlamlı bir farklılık göstermekte midir?)

Ortaokul öğrencilerinin etkileşimli tahta tutum ölçeğinden aldıkları toplam puanları öğrenim gördükleri sınıflara göre anlamlı bir farklılık gösterip göstermediğine dair bulgular ilişkisiz örneklemler için tek faktörlü varyans analizi (one way anova) ile belirlenmiş ve Tablo 3'te verilmiştir.

Tablo 3

Etkileşimli Tahta Tutum Ölçeği Puanlarının Öğrenim Gördükleri Sınıflara Göre Sonuçları

\begin{tabular}{|c|c|c|c|c|c|c|}
\hline \multicolumn{2}{|r|}{ Sinıf } & \multirow{2}{*}{$\begin{array}{c}\mathbf{N} \\
53\end{array}$} & \multicolumn{2}{|c|}{$\bar{X}$} & \multicolumn{2}{|c|}{$\mathbf{S}$} \\
\hline & 5 & & & 642 & 14, & \\
\hline & 6 & 55 & & 091 & 11, & \\
\hline & 7 & 66 & & 242 & 15, & \\
\hline & 8 & 51 & & 137 & 11, & \\
\hline & Toplam & 225 & & 022 & 13, & \\
\hline & $\begin{array}{c}\text { Varyansın } \\
\text { Kaynağı }\end{array}$ & $\begin{array}{l}\text { Kareler } \\
\text { Toplamı }\end{array}$ & sd & $\begin{array}{c}\text { Kareler } \\
\text { Ortalaması }\end{array}$ & $F$ & $p$ \\
\hline \multirow{3}{*}{ Sinıflar } & Gruplar arası & 3198,200 & 3 & 1066,067 & 5,990 & ,001 \\
\hline & Gruplar içi & 39330,449 & 221 & 177,966 & & \\
\hline & Toplam & 42528,649 & 224 & & & \\
\hline
\end{tabular}

Tablo 3’te de görüldüğü gibi, ilişkisiz örneklemler için tek faktörlü varyans analizi (ANOVA) kullanılarak elde edilen bulgulara göre, ortaokul öğrencilerinin etkileşimli tahta tutum ölçeğinden aldıkları toplam puanlar arasında, öğrenim gördükleri sınıflara göre anlamlı bir farklıık vardır $[F(3-221)=5,990, p<.05]$. Diğer bir ifadeyle, ortaokul öğrencilerinin etkileşimli tahtaya yönelik tutumları öğrenim gördükleri sınıflara göre değişmektedir. Bu farklılığın hangi gruplardan kaynaklandığını, bir başka deyişle farklılığı hangi grupların yaptığını belirlemek amacıyla yapılan LSD testi sonucunda, farklıığın; 5. Sınıfla 6., 7. Ve 8. Sınıflar arasında; 6. Sınıfla 5. Sınıf arasında; 7. Sınıfla 5. Sınıf arasında ve 8 sınıfla 5. Sınıf arasında olduğu belirlenmiştir.

Üçüncü araştırma sorusuna yönelik bulgular (Ortaokul öğrencilerinin etkileşimli tahta tutum ölçeğinden aldıkları puanlar tablet bilgisayar sahip olmalarına göre anlamlı bir farklılık göstermekte midir?)

Ortaokul öğrencilerinin etkileşimli tahta tutum ölçeğinden aldıkları toplam puanları tablet bilgisayar sahip olmalarına göre anlamlı bir farklılık gösterip göstermediğine dair bulgular ilişkisiz örneklemler $\mathrm{t}$ - testi ile belirlenmiş ve Tablo 4'te verilmiştir. 
Tablo 4

Etkileşimli Tahta Tutum Ölçeği Puanlarının Tablet Bilgisayara Sahip Olmalarına Göre Sonuçları

\begin{tabular}{ccccccc}
\hline $\begin{array}{c}\text { Tablet bilgisayara } \\
\text { sahip olma } \\
\text { durumu }\end{array}$ & $\mathbf{N}$ & $\bar{X}$ & $\mathbf{S}$ & $\mathbf{S d}$ & $\mathbf{T}$ & $\mathbf{p}$ \\
\hline Evet & 99 & 85,0101 & 12,60830 & 223 &,- 089 &, 929 \\
Hayır & 126 & 85,1746 & 14,68282 & & \\
\hline
\end{tabular}

$* P<0.05$

Tablo 4'te de görüldüğü gibi ${ }^{*} p<.05$ anlamlılık düzeyi için $.929>.05$ olduğu için sonuç anlamlı değildir. Ortaokul öğrencilerinin etkileşimli tahta tutum ölçeğinden aldıkları toplam puanların ortalaması (tablete sahip olanların ortalaması $\bar{X}=85,0101$; tablete sahip olmayanların ortalaması $\bar{X}=85,1746$ ) birbirine yakın çıkmıştır. Dolayısıyla Tablo 4 'te de görüldüğü gibi ${ }^{*} p<.05$ anlamlılık düzeyi için $.929>.05$ 'dir ve sonuç anlamlı değildir. Bir başka deyişle ortaokul öğrencilerinin etkileşimli tahtaya yönelik tutumları tablet bilgisayar sahip olmalarına göre anlamlı bir farklıık göstermemektedir.

Dördüncü araştırma sorusuna yönelik bulgular (Ortaokul öğrencilerinin etkileşimli tahta tutum ölçeğinden aldıkları puanlar haftalık internet kullanım sürelerine göre anlamlı bir farklılık göstermekte midir?)

Ortaokul öğrencilerinin etkileşimli tahta tutum ölçeğinden aldıkları toplam puanları haftalık internet kullanım sürelerine göre anlamlı bir farklılık gösterip göstermediğine dair bulgular ilişkisiz örneklemler için tek faktörlü varyans analizi (one way anova) ile belirlenmiş ve Tablo 5 'te verilmiştir. 
Tablo 5

Etkileşimli Tahta Tutum Ölçeği Puanlarının Haftalık Internet Kullanım Sürelerine Göre Sonuçları

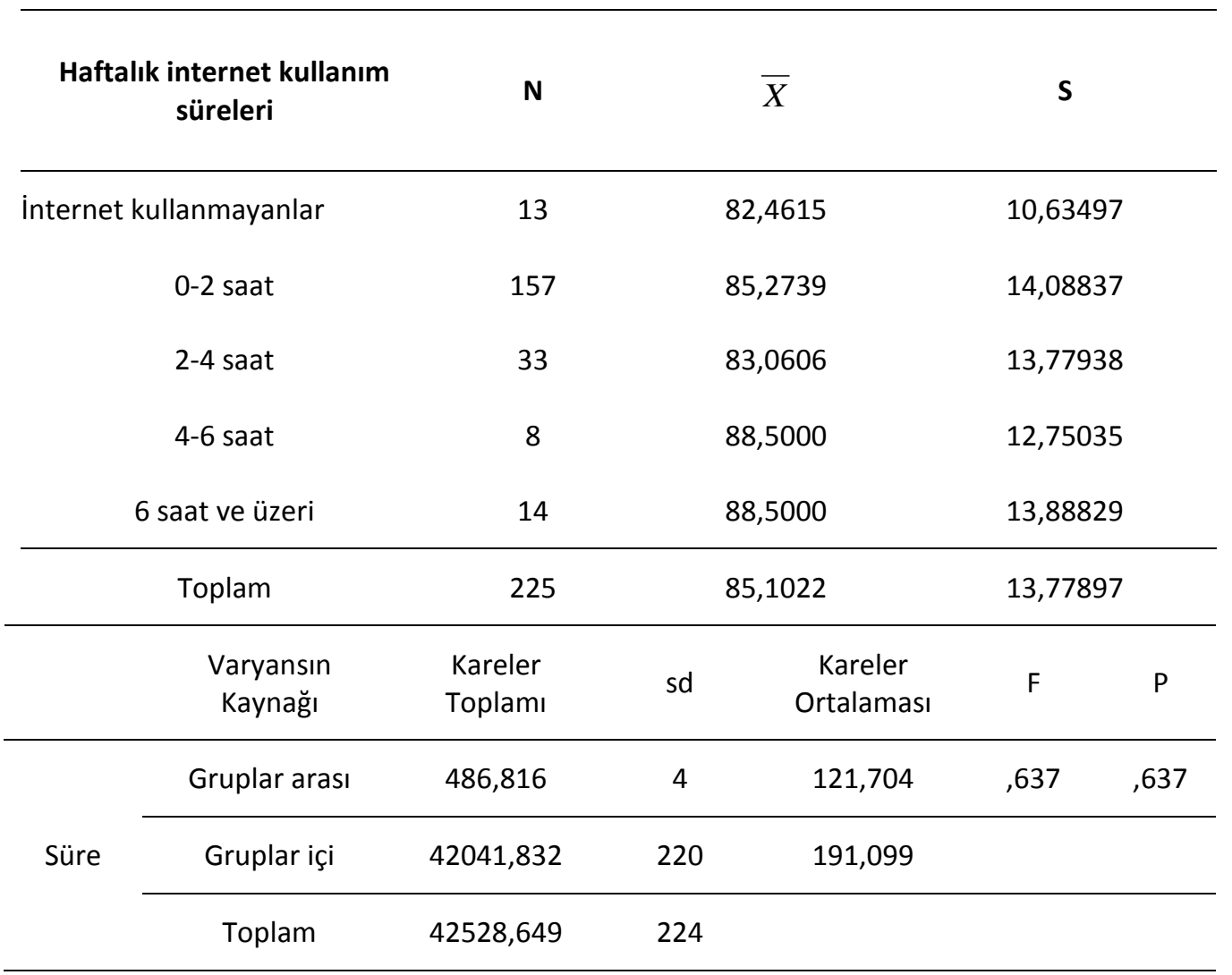

Tablo 5'te de görüldüğü gibi, ilişkisiz örneklemler için tek faktörlü varyans analizi (ANOVA) kullanılarak elde edilen bulgulara göre, ortaokul öğrencilerinin etkileşimli tahta tutum ölçeğinden aldıkları toplam puanlar arasında, haftalık internet kullanım sürelerine göre anlamlı bir farklılık yoktur $[F(4-220)=, 637, p>05]$. Diğer bir ifadeyle, ortaokul öğrencilerinin etkileşimli tahtaya yönelik tutumları haftalık internet kullanım sürelerine göre değişmemektedir.

Beşinci araştırma sorusuna yönelik bulgular (Ortaokul öğrencilerinin etkileşimli tahta tutum ölçeğinden aldıkları puanlar mobil cihaz sahip olma sürelerine göre anlamlı bir farklılık göstermekte midir?)

Ortaokul öğrencilerinin etkileşimli tahta tutum ölçeğinden aldıkları toplam puanlarının mobil cihaz sahip olma sürelerine göre anlamlı bir farklılık gösterip göstermediğine dair bulgular ilişkisiz örneklemler için tek faktörlü varyans analizi (one way anova) ile belirlenmiş ve Tablo $6^{\prime}$ da verilmiştir. 
Tablo 6

Etkileşimli Tahta Tutum Ölçeği Puanlarının Mobil Cihaz Sahip Olma Süreleri Göre Sonuçları

$\begin{array}{llll}\text { Mobil cihaz sahip olma süreleri } & \text { N } & \bar{X} & \text { S }\end{array}$

\begin{tabular}{|c|c|c|c|c|c|c|}
\hline \multicolumn{4}{|l|}{ Hiç kullanmayanlar } & 9 & 74,0000 & 9,12414 \\
\hline \multicolumn{4}{|l|}{ Çok Yetersiz } & 11 & 86,0909 & 12,20209 \\
\hline \multicolumn{4}{|l|}{ Yetersiz } & 12 & 84,0833 & 14,56308 \\
\hline \multicolumn{4}{|l|}{ Orta Düzeyde Yeterli } & 65 & 84,2923 & 11,36844 \\
\hline \multicolumn{4}{|l|}{ Yeterli } & 79 & 86,2532 & 15,89748 \\
\hline \multicolumn{4}{|l|}{ Çok Yeterli } & 49 & 86,3878 & 13,45953 \\
\hline \multirow[t]{2}{*}{ Toplam } & & & & 225 & 85,1022 & 13,77897 \\
\hline & $\begin{array}{l}\text { Varyansın } \\
\text { Kaynağı }\end{array}$ & Kareler Toplamı & sd & $\begin{array}{l}\text { Kareler } \\
\text { Ortalaması }\end{array}$ & $\mathrm{F}$ & $P$ \\
\hline \multirow{3}{*}{ Sahiplik } & $\begin{array}{l}\text { Gruplar } \\
\text { arası }\end{array}$ & 1360,808 & 5 & 272,162 & \multicolumn{2}{|l|}{1,448} \\
\hline & Gruplar içi & 41167,84 & 219 & 187,981 & & \\
\hline & Toplam & 42528,64 & 224 & & & \\
\hline
\end{tabular}

Tablo 6'da da görüldüğg̈ gibi, ilişkisiz örneklemler için tek faktörlü varyans analizi (ANOVA) kullanılarak elde edilen bulgulara göre, ortaokul öğrencilerinin etkileşimli tahta tutum ölçeğinden aldıkları toplam puanlar arasında, mobil cihaz sahip olma süreleri göre anlamlı bir farklılık yoktur $[F(5-219)=1,448, p>05]$. Diğer bir ifadeyle, ortaokul öğrencilerinin etkileşimli tahtaya yönelik tutumları mobil cihaz sahip olma süreleri göre değişmemektedir.

Altıncı araştırma sorusuna yönelik bulgular (Ortaokul öğrencilerinin etkileşimli tahta tutum ölçeğinden aldıkları puanlar mobil cihaz kullanımı yeterlilik düzeylerine göre anlamlı bir farklılık göstermekte midir?)

Ortaokul öğrencilerinin etkileşimli tahta tutum ölçeğinden aldıkları toplam puanların mobil cihaz kullanımı yeterlilik düzeylerine göre anlamlı bir farklılık gösterip göstermediğine dair bulgular ilişkisiz örneklemler için tek faktörlü varyans analizi (one way anova) ile belirlenmiş ve Tablo 7'de verilmiştir. 
Tablo 7

Etkileşimli Tahta Tutum Ölçeği Puanlarının Mobil Cihaz Kullanımı Yeterlilik Düzeylerine Göre Sonuçları

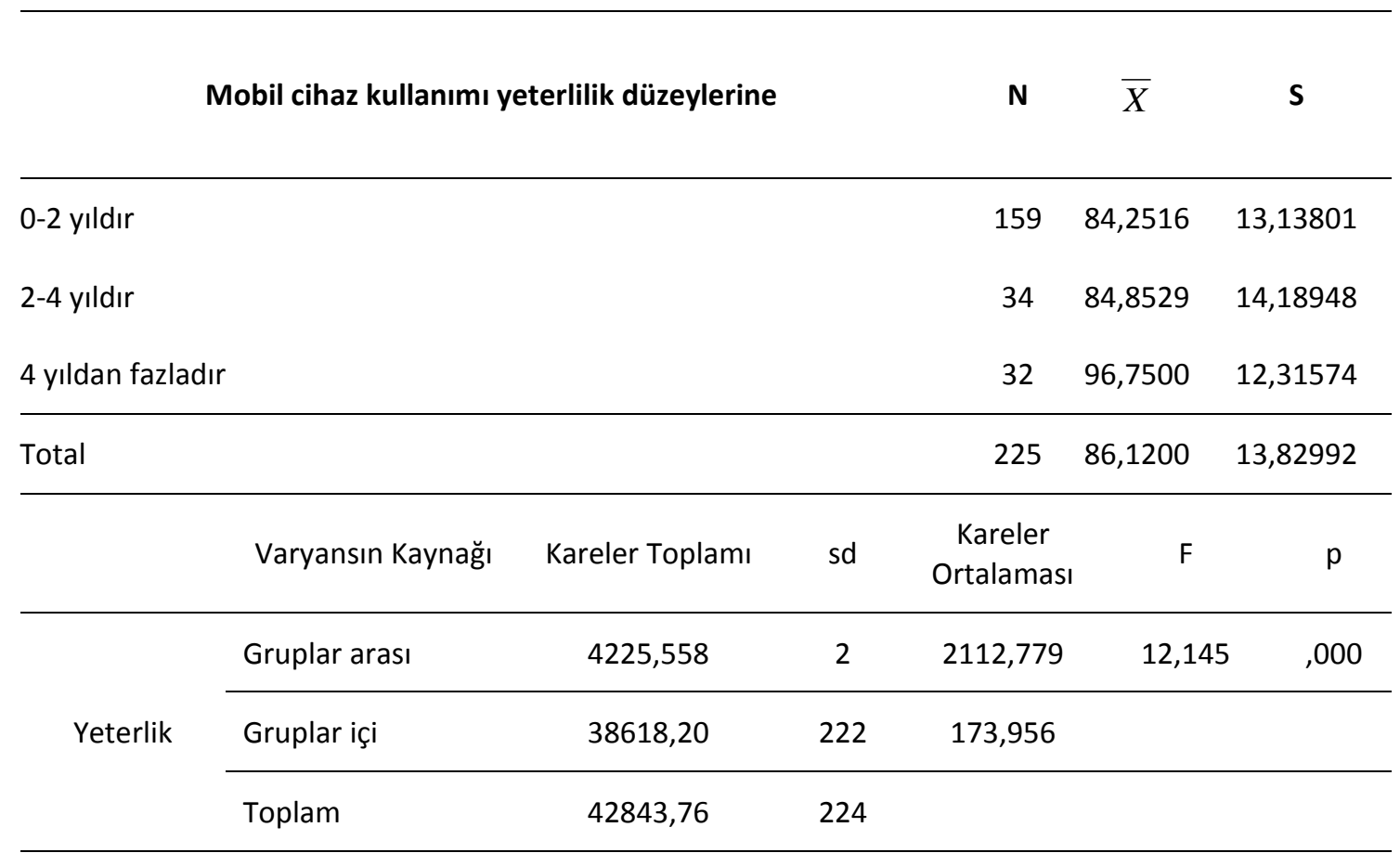

Tablo 7'de de görüldüğü gibi, ilişkisiz örneklemler için tek faktörlü varyans analizi (ANOVA) kullanılarak elde edilen bulgulara göre, ortaokul öğrencilerinin etkileşimli tahta tutum ölçeğinden aldıkları toplam puanlar arasında, mobil cihaz kullanımı yeterlilik düzeylerine göre anlamlı bir farklılık vardır $[F(2-222)=12,145, p<05]$. Diğer bir ifadeyle, ortaokul öğrencilerinin etkileşimli tahtaya yönelik tutumları mobil cihaz kullanımı yeterlilik düzeylerine göre değişmektedir. Bu farklılığın hangi gruplardan kaynaklandığını, bir başka deyişle farklılığı hangi grupların yaptığını belirlemek amacıyla yapılan LSD testi sonucunda, farklılığın; 0-2 yıldır ile 4 yıldan fazladır arasında; 2-4 yıldır ile 4 yıldan fazladır arasında; 4 yıldan fazladır ile 0-2 yıldır ve 2-4 yıldır arasında olduğu belirlenmiştir.

\subsection{Araştırmanın Nitel Kısmına Ait Bulgular}

"Derslerinizde Etkileşimli tahta kullanımı avantaj sağlamakta mıdır?” sorusuna yönelik cevapların analizi;

Görüşme yapılan öğrencilerden iki kız öğrenci dışında diğerleri derslerinde Etkileşimli tahta kullanımının yararlı olduğunu, avantaj sağladığını belirtmişlerdir. Kalan iki kişi ise Etkileşimli tahtanın fazla kullanılmamasından dolayı yararı olmadığını belirtmişlerdir. Öğrenciler Etkileşimli tahtanın farklı özelliklerine değinmişlerdir. Öğrencilerin bu soruya verdiği cevaplar gruplanıp temalar oluşturularak tablo haline getirilmiştir. 
Tablo 8

Derslerde Etkileşimli tahta Kullanımının Sağladığı Avantajlar

\begin{tabular}{|c|c|c|c|c|}
\hline \multirow[t]{2}{*}{ Kategori } & Tema & Kodlar & Freka & \\
\hline & & & 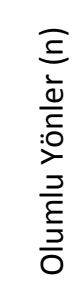 & 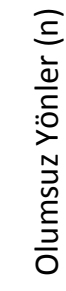 \\
\hline \multirow{6}{*}{ 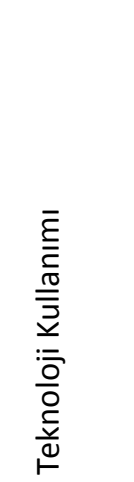 } & \multirow[t]{5}{*}{ Etkileşimli tahta Teknolojisi } & Görsellik & 9 & \\
\hline & & Kalıcılık & 5 & \\
\hline & & Verimlilik & 2 & \\
\hline & & Kullanıcı kolaylığı & 2 & \\
\hline & & Kullanım süresi & & 2 \\
\hline & Toplam & & 18 & 2 \\
\hline \multirow{3}{*}{ 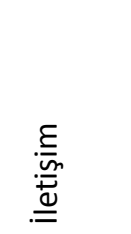 } & Etkileşim & & 2 & \\
\hline & Paylaşım & & 9 & \\
\hline & Toplam & & 11 & 0 \\
\hline \multirow[b]{3}{*}{ 咅 } & İlgi çekici & & 2 & \\
\hline & Eğlenceli & & 4 & \\
\hline & Toplam & & 6 & 0 \\
\hline
\end{tabular}

Öğrencilerin derslerde Etkileşimli tahta kullanımının sağladığı avantajlara verdiği cevaplar kodlanarak üç kategori oluşturulmuştur. Bu üç kategori Teknoloji Kullanımı, İletişim ve Etki olarak belirlenmiştir. Veriler belirlenen kategorilere göre gruplandırılarak temalar ve kodlar oluşturulmuştur.

Teknoloji Kullanımı kategorisinde Etkileşimli tahta teknolojisi teması için belirlenen kodlardan, Görsellik olumlu yönler $n=9$, Kalıcılık olumlu yönler $n=5$, Verimlilik olumlu yönler $n=2$, Kullanıcı kolaylığı olumlu yönler $n=2$ ve Kullanım süresi olumsuz yönler $n=2$ olarak belirlenmiştir. Öğrencilerin Etkileşimli tahta teknolojisi kullanımına yönelik olumlu görüşleri $\mathrm{n}=18$, olumsuz görüşleri ise $\mathrm{n}=2^{\prime}$ dir. İletişim kategorisinde bulunan temalardan, Etkileşim olumlu yönler $n=2$, Paylaşım olumlu yönler $n=9$, olarak belirlenmiştir. Öğrencilerin iletişim kategorisine yönelik olumlu görüşleri $n=11$, olumsuz görüşleri ise $n=0$ 'dır. Etki kategorisinde bulunan temalardan, ilgi çekici olumlu yönler $n=2$, Eğlenceli olumlu yönler $n=4$, olarak 
belirlenmiştir. Öğrencilerin etki kategorisine yönelik olumlu görüşleri $n=6$, olumsuz görüşleri ise $\mathrm{n}=0^{\prime}$ dır.

Etkileşimli tahtanın sağladığı avantajlara ilişkin bazı öğrencilerin görüşleri şöyledir;

“Çok fazla avantaj sağlıyor. Bazen internetten sitelere girip test çözüyoruz. Konularla ilgili video izliyoruz. Yani Etkileşimli tahtanın olması bizim için daha faydalı. Ama tabletle daha iyi olabilir." (Ö1)

"Derslerinizde Etkileşimli tahta kullanımı sizin derse karşı motivasyonunuzu ne yönde etkilemektedir?" sorusuna yönelik cevapların analizi;

Görüşme yapılan öğrencilerden sadece bir erkek öğrenci Etkileşimli tahta veya beyaz tahta kullanımının derslere karşı motivasyonunda herhangi bir değişiklik yapmadığını belirtmiştir. Diğerleri ise Etkileşimli tahta kullanımının derslere karşı motivasyonlarını olumlu, iyi yönde etkilediğini belirtmişlerdir. Öğrencilerin ikinci soruya verdiği cevaplar gruplanıp temalar oluşturularak tablo haline getirilmiştir.

Tablo 9

Derslerde Etkileşimli tahta Kullanımının Derse Karşı Öğrenci Motivasyonuna Etkisi

\begin{tabular}{llll}
\hline Kategori & Tema & Kodlar & Frekans \\
\hline
\end{tabular}

\begin{tabular}{|c|c|c|c|}
\hline & & 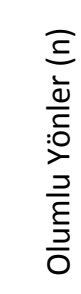 & 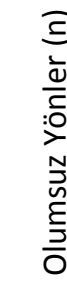 \\
\hline \multirow{8}{*}{ 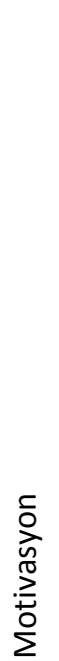 } & Derse Katılım & 5 & \\
\hline & Dikkat Çekme & 9 & \\
\hline & Görsellik & 6 & \\
\hline & Akıcılık & 6 & \\
\hline & Anlama & 5 & \\
\hline & Yaratıcılık & 2 & \\
\hline & Nötr & 1 & \\
\hline & Toplam & 34 & 0 \\
\hline
\end{tabular}

Öğrencilerin derslerde Etkileşimli tahta kullanımının derse karşı motivasyonlarına etkisine yönelik verilen cevaplar kodlanarak motivasyon kategorisi belirlenmiştir. Veriler belirlenen kategoriye göre gruplandırılarak temalar oluşturulmuştur. 
Motivasyon kategorisinde bulunan ana temalardan, Derse katılım olumlu yönler $n=5$, Dikkat çekme olumlu yönler $n=9$, Görsellik olumlu yönler $n=6$, Akıcılık olumlu yönler $n=6$, Anlama olumlu yönler $n=5$, Yaratıcılık olumlu yönler $n=2$, Nötr (Etkileşimli tahta ile beyaz tahta kullanımı arasında fark olmaması) $n=1$ olarak belirlenmiştir. Öğrencilerin motivasyon kategorisine yönelik olumlu görüşleri $n=34$, olumsuz görüşleri ise $n=0$ 'dır.

Derslerde Etkileşimli tahta kullanımının öğrencilerin derse karşı motivasyonlarına etkisine yönelik bazı öğrencilerin görüşleri şöyledir;

"Olumlu yönde etkilemektedir. Çoğu öğrencinin dikkatini çekmektedir. Derslerimi daha iyi anlamamızı sağlar." (Ö16)

"Derslerinizde Etkileşimli tahta kullanımı sınıf ortamını ve etkileşimi ne yönde etkilemektedir?" sorusuna yönelik cevapların analizi;

Görüşme yapılan öğrencilerden bir erkek öğrenci Etkileşimli tahta kullanımının sınıf ortamını sosyalleşme yönünden kötü etkilediğini belirtmiştir. Başka iki erkek öğrenci de sınıfta Etkileşimli tahta kullanmayı herkes istediği için sorun oluştuğunu ve daha çok konuşulduğunu belirtmiştir. Diğer öğrenciler derslerde Etkileşimli tahta kullanımının sınıf ortamını olumlu etkilediğini belirtmişlerdir. Öğrencilerin üçüncü soruya verdiği cevaplar gruplanıp temalar oluşturularak tablo haline getirilmiştir. 
Tablo 10

Derslerde Etkileşimli tahta Kullanımının Sınıf Ortamı Ve Etkileşime Etkisi

\begin{tabular}{lll}
\hline Kategori Tema & Kodlar & Frekans \\
\hline
\end{tabular}

\begin{tabular}{|c|c|c|c|c|}
\hline & & & 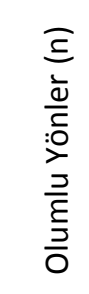 & 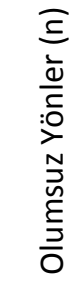 \\
\hline \multirow{6}{*}{ 䓛 } & Etkileşim & & 4 & 1 \\
\hline & Katılım & & 3 & \\
\hline & \multirow[t]{3}{*}{ Düzen } & Sessiz ortam & 2 & 1 \\
\hline & & Eğlenceli & 2 & \\
\hline & & Kullanıcı belirleme sorunu & & 1 \\
\hline & Toplam & & 11 & 3 \\
\hline & Araştırma & & 4 & \\
\hline & Kalıcilık & & 3 & \\
\hline & Anlama & & 7 & \\
\hline & İlgi ile dinleme & & 9 & \\
\hline 㖖 & Toplam & & 23 & 0 \\
\hline
\end{tabular}

Öğrencilerin derslerde Etkileşimli tahta kullanımının sınıf ortamı ve etkileşime etkisine yönelik verdiği cevaplar kodlanarak iki kategori oluşturulmuştur. Bu iki kategori iletişim ve Etki olarak belirlenmiştir. Veriler belirlenen kategorilere göre gruplandırılarak temalar ve kodlar oluşturulmuştur.

Iletişim kategorisinde bulunan temalardan Etkileşim olumlu yönleri $n=4$, olumsuz yönleri=1, Katılım olumlu yönleri $n=3$, Düzen kategorisinde bulunan alt temalardan Sessiz ortam olumlu yönleri $n=2$, olumsuz yönleri $n=1$, Eğlenceli olumlu yönleri $n=2$, Kullanıcı belirleme sorunu olumsuz yönleri $n=1$ olarak belirlenmiştir. Öğrencilerin iletişim kategorisine yönelik olumlu görüşleri $n=11$, olumsuz görüşleri ise $n=3$ olmuştur. Etki kategorisinde bulunan ana temalardan, Araştırma olumlu yönler $n=4$, Kalıcılık olumlu yönler $n=3$, Anlama olumlu yönler $n=7$, İlgi ile dinleme olumlu yönler $n=9$ olarak belirlenmiştir. Öğrencilerin etki kategorisine yönelik olumlu görüşleri $n=23$, olumsuz görüşleri ise $n=0$ 'dır. 
Derslerde Etkileşimli tahta kullanımının sınıf ortamı ve etkileşime etkisine yönelik bazı öğrencilerin görüşleri şöyledir;

"Derse ortak katılma yönünden ve dinleme yönünden tabi ki iyi yönde etkiliyor." (Ö6)

"Derslerinizde Etkileşimli tahta kullanımının en çok sevdiğiniz ya da sevmediğiniz yönü / yönleri ne olmuştur?" sorusuna yönelik cevapların analizi;

Görüşme yapılan öğrencilerden bir kız öğrenci, arkadaşlarının Etkileşimli tahtayı dersle alakasız ve izin almadan kullanmalarını sevmediğini belirtmiştir. Bir erkek ve bir kız öğrenci Etkileşimli tahtanın geç açılması ve yapılanları geç algılamasının sevmediği yönleri olduğunu belirtmişlerdir. Bir kız öğrenci Etkileşimli tahta bozulduğunda düzelmesinin zaman almasını olumsuz özellik olarak belirtmiştir. Bir kız öğrenci Etkileşimli tahtanın gözler için zararlı olabileceğini belirtmiştir. Bir erkek öğrenci Etkileşimli tahtanın radyasyon yaymasını olumsuz özellik olarak belirtmiştir. Diğer öğrenciler ise Etkileşimli tahtanın sevmedikleri, olumsuz özelliği olmadığını belirtmişlerdir. Sevdikleri özellikler ise ilgilerini artırması, görsellik katması ve konuları pekiştirmesi, test çözmeleri, dersleri daha verimli hale getirmesi, kolaylık sağlaması ve eğlenceli olması şeklinde belirtmişlerdir. Öğrencilerin dördüncü soruya verdiği cevaplar gruplanıp temalar oluşturularak tablo haline getirilmiştir. 
Tablo 11

Derslerde Etkileşimli tahta Kullanımının Sevilen Ve Sevilmeyen Yönleri

\begin{tabular}{llll}
\hline Kategori Tema & Kodlar & Frekans \\
\hline
\end{tabular}

\begin{tabular}{|c|c|c|c|c|}
\hline & & & 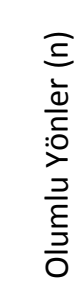 & \\
\hline \multirow{7}{*}{ 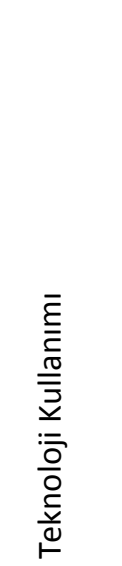 } & \multirow[t]{6}{*}{ Etkileşimli tahta Teknolojisi } & Görsellik & 13 & \\
\hline & & Pekiştirme & 5 & \\
\hline & & Verimlilik & 4 & \\
\hline & & Kullanıcı kolaylığı & 4 & \\
\hline & & Eğlenceli & 6 & \\
\hline & & Kullanım sıklığı & & 1 \\
\hline & Toplam & & 32 & 1 \\
\hline \multirow[t]{5}{*}{ Alt Yapı } & Donanım & Geç açılma, donma & & 2 \\
\hline & & Bozulduğunda zaman alması & & 1 \\
\hline & & Ders dışı ve izinsiz kullanım & & 2 \\
\hline & Yazılım & Güncelleme & & 1 \\
\hline & Toplam & & 0 & 6 \\
\hline \multirow{3}{*}{ 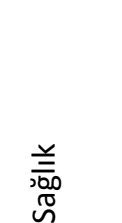 } & Gözleri etkilemesi & & & 2 \\
\hline & Radyasyon yayması & & & 1 \\
\hline & Toplam & & 0 & 2 \\
\hline
\end{tabular}

Öğrencilerin derslerde Etkileşimli tahta kullanımının sevilen ve sevilmeyen yönleri ile ilgili verdiği cevaplar kodlanarak üç kategori oluşturulmuştur. Bu üç kategori Teknoloji Kullanımı, Alt Yapı ve Sağlık olarak belirlenmiştir. Veriler belirlenen kategorilere göre gruplandırılarak temalar ve kodlar oluşturulmuştur.

Teknoloji Kullanımı kategorisinde Etkileşimli tahta teknolojisi teması için belirlenen kodlardan, Görsellik olumlu yönler $n=13$, Pekiştirme olumlu yönler $n=5$, Verimlilik olumlu 
yönler $n=4$, Kullanıcı kolaylığı olumlu yönler $n=4$, Eğlenceli olumlu yönler $n=6$ ve Kullanım sıklığı olumsuz yönler $n=1$ olarak belirlenmiştir. Öğrencilerin Etkileşimli tahta teknolojisi kullanımına yönelik olumlu görüşleri $n=32$, olumsuz görüşleri ise $n=1^{\prime}$ dir. Alt Yapı kategorisinde Donanım teması için belirlenen kodlardan, Geç açılma, donma olumsuz yönler $n=2$, Bozulduğunda zaman alması olumsuz yönler $n=1$, Ders dışı izinsiz kullanım olumsuz yönler $n=2$, Yazılım ana temasında olan Güncelleme alt teması olumsuz yönler $n=1$ olarak belirlenmiştir. Öğrencilerin alt yapı kategorisine yönelik olumlu görüşleri $n=0$, olumsuz görüşleri ise $n=6^{\prime}$ dır. Sağlık kategorisinde bulunan temalardan, Gözleri etkilemesi olumsuz yönler $n=1$, Radyasyon yayması olumsuz yönler $n=1$ olarak belirlenmiştir. Öğrencilerin sağlık kategorisine yönelik olumlu görüşleri $n=0$, olumsuz görüşleri ise $n=2$ 'dir.

Derslerde Etkileşimli tahta kullanımının sevilen ve sevilmeyen yönlerine ilişkin bazı öğrencilerin görüşleri şöyledir;

"Internete girip test çözüyoruz, videolar izliyoruz. Bazı anlamadığımız konuları Etkileşimli tahtadan açarak öğreniyoruz. Tahtadan açıınca tüm arkadaşlarımızın dikkatini çekiyor ve herkes derse katılıyor." (Ö2)

"Sevmediğim yönleri Etkileşimli tahtayı izinsiz açmaları dersle alakalı kullanmamaları ve derste hocadan izinsiz kullanmaları." (Ö9)

"Derslerinizde Etkileşimli tahta kullanımının daha etkili hale getirilmesi için hangi önerilerde bulunursunuz?" sorusuna yönelik cevapların analizi;

Görüşme yapılan öğrencilerden iki kız öğrenci Etkileşimli tahtalara şifre koyulması gerektiğini ve gereksiz oyun oynanmaması gerektiğini belirtmişlerdir. Bir erkek ve bir kız öğrenci Etkileşimli tahtalara format atılması ve virüslerden temizlenmesi gerektiğini belirtmişlerdir. Bir kız öğrenci sınıf perdelerinin ortama uygun olması gerektiğini belirtmiştir. Dört kız ve bir erkek öğrenci tablet dağıtılmasını istediklerini belirtmiştir. İki erkek öğrenci dere göre program yüklenebileceğini ve derslerde eğitim bilişim ağı (eba) gibi sitelerin kullanılabileceğini belirtmiştir. Öğrencilerin beşinci soruya verdiği cevaplar gruplanıp temalar oluşturularak tablo haline getirilmiştir. 
Tablo 12

Derslerde Etkileşimli tahtanın Daha Etkili Kullanılmasına Yönelik Öğrenci Önerileri

\begin{tabular}{|c|c|c|c|}
\hline Kategori & Tema & Kodlar & Frekans \\
\hline \multirow{3}{*}{ 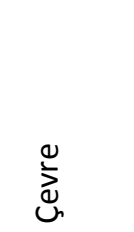 } & \multirow[t]{2}{*}{ Ortam özelliği } & Sınıf perdelerinin uygun olması & 1 \\
\hline & & Ortamı yenileme & 2 \\
\hline & \multicolumn{2}{|l|}{ Toplam } & 2 \\
\hline & \multirow[t]{3}{*}{ Güvenlik } & Formatla yenilenmesi & 2 \\
\hline & & Virüs koruması & 1 \\
\hline & & Şifre koyma & 2 \\
\hline & \multirow[t]{2}{*}{ Destekleme } & Tablet desteği & 5 \\
\hline & & Fare, klavye vb. donanım desteği & 1 \\
\hline & \multirow[t]{5}{*}{ Yazılım } & Derse göre yazılım yüklenmesi & 4 \\
\hline & & Eğitim bilişim ağı (eba) kullanımı & 2 \\
\hline & & Etkili kullanım & 6 \\
\hline & & İnternet kullanımı & 8 \\
\hline \multirow{2}{*}{$\begin{array}{l}\frac{\overline{2}}{\pi} \\
\frac{1}{4}\end{array}$} & & Gereksiz oyun vb. yazılım yüklenmemesi & 1 \\
\hline & \multicolumn{2}{|l|}{ Toplam } & 33 \\
\hline
\end{tabular}

Öğrencilerin derslerde Etkileşimli tahta kullanımının daha etkili hale getirilmesi için verdiği öneriler kodlanarak iki kategori oluşturulmuştur. Bu iki kategori Çevre ve Alt Yapı olarak belirlenmiştir. Veriler belirlenen kategorilere göre gruplandırılarak temalar ve kodlardan oluşturulmuştur.

Çevre kategorisinde bulunan Ortam özelliği ana temasında olan kodlar, Sınıf perdelerinin uygun olması $n=1$, Ortamı yenileme $n=1$ olarak belirlenmiştir. Alt Yapı kategorisinde bulunan Güvenlik temasında olan kodlar Formatla yenilenmesi $n=2$, Virüs koruması $n=1$, Şifre koyma $n=2$, Destekleme temasında olan kodlar Derse göre yazılım yüklenmesi $n=4$, Eğitimde bilişim ağı (eba) kullanımı $n=2$, Etkili kullanım $n=6$, İnternet kullanımı $n=8$, Gereksiz oyun vb. yazılım yüklenmemesi $n=1$ olarak belirlenmiştir.

Derslerde Etkileşimli tahta kullanımının daha etkili hale getirilmesi için verilen öneriler ile ilgili bazı öğrencilerin görüşleri şöyledir:

"Etkileşimli tahtaların formatla temizlenmesi ve yeniden yüklenmesi daha iyi olur ve virüs vb. durumlardan korunmuş olur." (Ö6)

"Sınıf perdelerinin camlara uygun olması gerekir." (Ö26) 
"Derslerinizde geleneksel yöntemler (Beyaz tahta kullanımı) ile Etkileşimli tahta kullanımı arasında bir kıyaslama yapsanız hangisini tercih edersiniz? Neden?" sorusuna yönelik cevapların analizi;

Görüşme yapılan öğrencilerden, bir kız ve bir erkek öğrenci derslerde beyaz tahta kullanıldığında sınıf düzeninin daha iyi ve sessiz olmasından dolayı beyaz tahta kullanımını tercih ettiklerini belirtmiştir. Bir kız öğrenci Etkileşimli tahtanın gözleri ağrıtmasından dolayı beyaz tahtayı tercih ettiğini belirtmiştir. Bir erkek öğrenci ikisinin de dersine katkı sağladığını belirtmiştir. Diğer öğrenciler derste Etkileşimli tahta kullanımını tercih ettiklerini belirtmişlerdir. Öğrencilerin altıncı soruya verdiği cevaplar gruplanıp temalar ve kodlar oluşturularak tablo haline getirilmiştir.

Tablo 13

Geleneksel Yöntemler ve Etkileşimli tahta Kullanımına Yönelik Öğrenci Görüşleri

\begin{tabular}{lll}
\hline Kategori Tema Kodlar & Frekans \\
\hline
\end{tabular}

\begin{tabular}{|c|c|c|c|c|}
\hline & & & 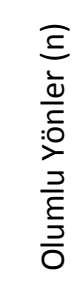 & 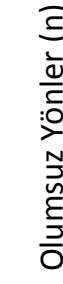 \\
\hline \multirow{5}{*}{ 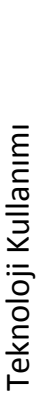 } & \multirow[t]{4}{*}{ Etkileşimli tahta Teknolojisi } & Görsellik & 9 & \\
\hline & & Kalıcılık & 3 & \\
\hline & & Kullanışıııık & 8 & \\
\hline & & Kullanıcı kolaylığı & 5 & \\
\hline & Toplam & & 25 & 0 \\
\hline \multirow{6}{*}{$\frac{\varepsilon}{\stackrel{E}{\underline{m}}}$} & Etkileşim & & 5 & 2 \\
\hline & Araştırma & & 4 & \\
\hline & Eğlenceli & & 3 & \\
\hline & İlgi çekici & & 5 & \\
\hline & Toplam & & 17 & 2 \\
\hline & Sağlık & Gözleri ağrıtması & & 1 \\
\hline 妾 & Toplam & & 0 & 1 \\
\hline
\end{tabular}

Öğrencilerin derslerde beyaz tahta kullanımı ile Etkileşimli tahta kullanımı arasında karşılaştırma yapmaları ile ilgili verdiği cevaplar kodlanarak üç kategori oluşturulmuştur. Bu üç 
kategori Teknoloji Kullanımı, İletişim ve Etki olarak belirlenmiştir. Veriler belirlenen kategorilere göre gruplandırılarak temalar ve kodlar oluşturulmuştur.

Teknoloji Kullanımı kategorisinde Etkileşimli tahta teknolojisi teması için belirlenen kodlardan, Görsellik olumlu yönler $n=9$, Kalıcılık olumlu yönler $n=3$, Kullanışlılık olumlu yönler $n=8$, Kullanıcı kolaylığı olumlu yönler $n=5$ olarak belirlenmiştir. Öğrencilerin Etkileşimli tahta teknolojisi kullanımına yönelik olumlu görüşleri $n=25$, olumsuz görüşleri ise $n=0$ 'dır. İletişim kategorisinde bulunan temalardan, Etkileşim olumlu yönler $n=5$, olumsuz yönler $n=2$, Araştırma olumlu yönler $n=4$, Eğlenceli olumlu yönler $n=3$, İlgi çekici olumlu yönler $n=5$ olarak belirlenmiştir. Öğrencilerin iletişim kategorisine yönelik olumlu görüşleri $n=17$, olumsuz görüşleri ise $n=2$ 'dir. Etki kategorisinde bulunan Sağlık temasında Gözleri ağrıtması koduna yönelik olumsuz yönler $n=1$ olarak belirlenmiştir.

Derslerde beyaz tahta kullanımı ile Etkileşimli tahta kullanımı arasında karşılaştırma yapmaları ile ilgili bazı öğrencilerin görüşleri şöyledir:

"Etkileşimli tahtada daha çok katılım olurken beyaz tahtada ders işlerken az katılım oluyor." (Ö10)

"Etkileşimli tahtayı tercih ederim. Çünkü daha aktif ve renkli." (Ö13).

\section{SONUÇ, TARTIŞMA VE ÖNERILER}

Etkileşimli tahta ile ilgili yapılan çalışmalarda genellikle Etkileşimli tahtanın öğrenci başarısı, tutum veya motivasyona etkisi incelendiği görülmektedir. Amacı etkileşimli tahtanın eğitimde kullanılmasına yönelik ortaokul öğrencilerinin görüşlerinin incelenmesi olan ve 225 ortaokul öğrencisinin [113 (\% 50,2)'si kız, 112 (\% 49,8)'i erkektir] katılımı ile gerçekleştirilen bu çalışmanın bulgularından ulaşılan sonuçlar şu şekildedir: Araştırmanın nicel verilerinden elde edilen bulgulardan ortaya çıkan sonuçlara göre; ortaokul öğrencilerinin etkileşimli tahta tutum ölçeğinden aldıkları toplam puanların ortalaması (erkeklerin ortalaması $\bar{X}=85,4911 ;$ kızların ortalaması $\bar{X}=84,7168$ ) birbirine yakın çıkmıştır, dolayısıyla Tablo 2'den de görüldüğü gibi ${ }^{*} p<.05$ anlamlılık düzeyi için $.674>.05$ 'dir ve sonuç anlamlı değildir. Bir başka deyişle ortaokul öğrencilerinin etkileşimli tahtaya yönelik tutumları cinsiyet durumlarına göre anlamlı bir farklıık göstermemektedir. Benzer çalışmalarda cinsiyete göre farklılıklara bakıldığında farklı sonuçların ortaya çıktığı görülmektedir. Etkileşimli tahta kullanımına yönelik tutumların cinsiyete göre anlamlı farklıık bulan (Kaya ve Aydın, 2011; Aytaç, 2013) çalışmaların yanında farklıık bulmayan çalışmalar da vardır (Demircioğlu ve Demircioğlu, 2015; Zengin, Kırılmazkaya ve Keçeci, 2011; Muhanna ve Nejem, 2013). Ortaokul öğrencilerinin etkileşimli tahta tutum ölçeğinden aldıkları toplam puanlar arasında, öğrenim gördükleri sınıflara göre anlamlı bir farklılık vardır $[F(3-221)=5,990, p<.05]$. Diğer bir ifadeyle, ortaokul öğrencilerinin etkileşimli tahtaya yönelik tutumları öğrenim gördükleri sınıflara göre değişmektedir. Bu farklılığın hangi gruplardan kaynaklandığını, bir başka deyişle farklılığı hangi grupların yaptığını belirlemek amacıyla yapılan LSD testi sonucunda, farklıı̆ıı; 5. Sınıfla 6., 7. ve 8. Sınıflar arasında; 6. Sınıfla 5. Sınıf arasında; 7. Sınıfla 5. Sınıf arasında ve 8 sınıfla 5. Sınıf arasında olduğu belirlenmiştir (Tablo 3). Benzer şekilde Demircioğlu ve Demircioğlu (2015) da yaptıkları çalışmada öğrencilerin Etkileşimli tahtaya yönelik tutumlarının sınıf seviyesine göre anlamlı farklılık olduğu sonucuna ulaşmışlardır. Bu farklıı̆ın, sınıf seviyesi ilerledikçe öğrencilerin Etkileşimli tahtaya yönelik tutumlarının azalması yönünde olduğu görülmektedir. Ortaokul öğrencilerinin etkileşimli tahta tutum ölçeğinden aldıkları toplam puanların ortalaması (tablete sahip olanların ortalaması $\bar{X}=85,0101$; tablete sahip olmayanların ortalaması $\bar{X}=85,1746$ ) birbirine yakın çıkmıştır, dolayısıyla Tablo 4'den de görüldüğü gibi ${ }^{*} p<.05$ anlamlılık düzeyi için $.929>$ .05 'dir ve sonuç anlamlı değildir. Bir başka deyişle ortaokul öğrencilerinin etkileşimli tahtaya 
yönelik tutumları tablet bilgisayar sahip olmalarına göre anlamlı bir farklılık göstermemektedir (Tablo 4). Ortaokul öğrencilerinin etkileşimli tahta tutum ölçeğinden aldıkları toplam puanlar arasında, haftalık internet kullanım sürelerine göre anlamlı bir farklılık yoktur $[F(4-220)=, 637$, $p>05]$. Diğer bir ifadeyle, ortaokul öğrencilerinin etkileşimli tahtaya yönelik tutumları haftalık internet kullanım sürelerine göre değişmemektedir (Tablo 5). Ortaokul öğrencilerinin etkileşimli tahta tutum ölçeğinden aldıkları toplam puanlar arasında, mobil cihaz sahip olma süreleri göre anlamlı bir farklılık yoktur $[F(5-219)=1,448, p>05]$. Diğer bir ifadeyle, ortaokul öğrencilerinin etkileşimli tahtaya yönelik tutumları mobil cihaz sahip olma süreleri göre değişmemektedir (Tablo 6). Ortaokul öğrencilerinin etkileşimli tahta tutum ölçeğinden aldıkları toplam puanlar arasında, mobil cihaz kullanımı yeterlilik düzeylerine göre anlamlı bir farklılık vardır $[F(2-222)=12,145, p<05]$. Diğer bir ifadeyle, ortaokul öğrencilerinin etkileşimli tahtaya yönelik tutumları mobil cihaz kullanımı yeterlilik düzeylerine göre değişmektedir. Bu farklılığın hangi gruplardan kaynaklandığını, bir başka deyişle farklıığı hangi grupların yaptığını belirlemek amacıyla yapılan LSD testi sonucunda, farklılığın; 0-2 yıldır ile 4 yıldan fazladır arasında; 2-4 yıldır ile 4 yıldan fazladır arasında; 4 yıldan fazladır ile 0-2 yıldır ve 2-4 yıldır arasında olduğu belirlenmiştir (Tablo 7). Çelik ve Bindak (2005) ise çalışmalarında bilgisayarı olan öğretmenlerin olmayan öğretmenlere göre bilgisayara yönelik olumlu tutumlarının anlamlı derecede yüksek olduğu sonucuna ulaşmışlardır. Yapılan çalışmalara bakıldığında akılı tahtanın olumlu sonuçlar ortaya çıkardığı görülmektedir. Etkileşimli tahtalar öğrencilerin derse karşı ilgi ve motivasyonlarını arttırmıştır (Sevindik ve Gürol, 2009). Hall ve Chamlee (2009) derslerde Etkileşimli tahta kullanımının daha iyi zaman yönetimi sağladığını ortaya koymuşlardır. Haldane (2007) Etkileşimli tahta kullanımının öğrenci başarısını arttırdığını belirtmiştir. Smith, Hardman ve Higgins (2006) çalışmalarında Etkileşimli tahta kullanımının derslerin daha hızlı geçmesini sağladığını ve grup çalışmalarında daha az zaman harcandığını belirtmişlerdir. Solvie (2004) ve Tate_(2002) çalışmalarında Etkileşimli tahta kullanımının öğrencilerin derse olan ilgi, katılım ve dikkatlerini arttırdığını, Bell (1998) Etkileşimli tahtanın etkileşimli kullanım sayesinde öğrencilerin öğrenmesini olumlu yönde arttırdığını, Türel ve Johnson (2012) Etkileşimli tahta kullanımının öğretim stratejilerini olumlu yönde etkilediğini ortaya koymuşlardır. Erduran ve Tataroğlu (2009) çalışmalarında Etkileşimli tahta kullanımının öğrenme ortamı üzerinde olumlu etki oluşturduğunu, öğrenci ilgisini arttırdığını, öğrencilerin dersi daha iyi anladıklarını ve öğrencilerin derste sıkılmadıklarını belirtmişlerdir. Araştırmanın nitel verilerinden elde edilen bulgulardan ortaya çıkan sonuçlara göre; Öğrencilerin "Derslerinizde Etkileşimli tahta kullanımı avantaj sağlamakta mıdır?" sorusuna verdikleri cevaplar 3 kategori altında toplanmıştır. Bu kategoriler, Teknoloji Kullanımı, Iletişim ve Etki olarak belirlenmiştir. Teknoloji Kullanımı kategorisinde Etkileşimli tahta teknolojisi teması için belirlenen kodlardan, yoğun olarak; Görsellik olumlu yönler $n=9$, Kalıcllık olumlu yönler $n=5$; illetişim kategorisinde yoğun olarak paylaşım $n=9$ olarak; Etki kategorisinde yoğun olarak eğlenceli $n=4$ olarak görüş belirttikleri belirlenmiştir. Öğrencilerin "Derslerinizde Etkileşimli tahta kullanımı sizin derse karşı motivasyonunuzu ne yönde etkilemektedir?" sorusuna verdikleri cevaplar 1 kategori altında toplanmıştır. Bu kategori Motivasyon olarak ortaya çıkmıştır. Bu kategoride yoğun olarak dikkat çekme teması $n=9$ olarak görüş belirttikleri belirlenmiştir. Öğrencilerin "Derslerinizde Etkileşimli tahta kullanımı sınıf ortamını ve etkileşimi ne yönde etkilemektedir?" sorusuna verdikleri cevaplar 2 kategori altında toplanmıştır. Bu kategoriler Illetişim ve etki olarak ortaya çıkmıştır. İletişim kategorisinde yoğun olarak, Etkileşim teması $n=4$ ve Etki kategorisinde ilgi ile dinleme teması $\mathrm{n}=9$ olarak görüş belirttikleri belirlenmiştir. Öğrencilerin "Derslerinizde Etkileşimli tahta kullanımının en çok sevdiğiniz ya da sevmediğiniz yönü / yönleri ne olmuştur?" sorusuna verdikleri cevaplar 3 kategori altında toplanmıştır. Bu üç kategori Teknoloji Kullanımı, Alt Yapı ve Sağılık olarak belirlenmiştir. Teknoloji kullanımı kategorisinde yoğun olarak, görsellik kodu $n=13$; Alt yapı kategorisinde yoğun olarak Geç açılma, donma $n=2$ ve Ders dışı ve izinsiz kullanım $n=2$, sağlık kategorisinde gözleri etkilemesi $n=2$ olarak görüş belirttikleri belirlenmiştir. 
Öğrencilerin "Derslerinizde Etkileşimli tahta kullanımının daha etkili hale getirilmesi için hangi önerilerde bulunursunuz?" sorusuna verdikleri cevaplar 2 kategori altında toplanmıştır. Bu kategoriler Çevre ve Alt Yapı olarak ortaya çıkmıştır. Çevre kategorisinde yoğun olarak, Ortamı yenileme $n=2$ ve Internet kullanımı $n=8$ olarak görüş belirttikleri belirlenmiştir. Öğrencilerin "Derslerinizde geleneksel yöntemler (Beyaz tahta kullanımı) ile Etkileşimli tahta kullanımı arasında bir kıyaslama yapsanız hangisini tercih edersiniz? Neden?" sorusuna verdikleri cevaplar 3 kategori altında toplanmıştır. Bu kategoriler Teknoloji Kullanımı, Iletişim ve Etki olarak ortaya çıkmıştır. Teknoloji Kullanımı kategorisinde yoğun olarak, Görsellik n=9; İletişim kategorisinde yoğun olarak, Etkileşim ve illgi çekici $n=9$; Etki kategorisinde yoğun olarak Sağlık n=1 olarak görüş belirttikleri belirlenmiştir. Araştırma sonuçlarından hareketle; ortaokul öğrencilerinin gelişim ve değişim süreçleri gözlenerek eksiklikler tespit edilmesi, bu eksikliklerin giderilmesi için eğitim-öğretim planlamalarının yapılması, bilgi ve iletişim teknolojilerinin entegrasyon sürecinde katkıyı artırmak için öğrencilerin bilgi ve becerilerinin artırılmasının önemli olduğu söylenebilir. Derslerde Etkileşimli tahta kullanımı arttıkça dersler daha verimli ve etkili geçebilir. Öğretmen ve öğretmen adaylarına hızla gelişen eğitim teknolojisine ayak uydurmaları için Etkileşimli tahta konusunda bilgilendirme ve eğitim verilebilir. Etkileşimli tahta kullanımı öğrencilerin derse aktif katılımını, etkileşimi, derse olan ilgi, motivasyon ve dikkatlerini arttırmaktadır. Bu da öğrenci başarısının zamanla artacağını göstermektedir. Öğretmenlere bu konuda farkındalık kazandırmak önemlidir.

\section{KAYNAKLAR}

AECT. (2004, June). The Definition of Educational Technology. By Association for Educational Communications and Technology (AECT) Definition and Terminology Committee. Erişim tarihi: 26 Aralık 2015, http://ocw.metu.edu.tr/file.php/118/molenda_definition.pdf

Akkoyunlu, B. (1995). Bilgi teknolojilerinin okullarda kullanımı ve öğretmenlerin rolü. Hacettepe Üniversitesi Eğitim Fakültesi Dergisi, 11, 105-109.

Akkoyunlu, B. (1998). Eğitimde teknolojik gelişmeler. B. Özer (Ed.), Çağdaş eğitimde yeni teknolojiler (ss. 1-12). Eskişehir: Anadolu Üniversitesi Yayınları.

Aktan, C. ve Tunç, M. (1998, Ocak-Şubat). Bilgi toplumu ve Türkiye. Yeni Türkiye Dergisi, 118134.

Aytaç, T. (2013). Interactive whiteboard factor in education: Students' points of view and their problems. Academic Journals Educational Research and Reviews, Vol. 8(20), 19071915.

Bell, A.M. (1998). Teachers' perceptions regarding the use of the interactive electronic whiteboard in instruction. Erişim Tarihi: 28 Haziran 2016, http://downloads01.smarttech.com/media/sitecore/en/pdf/research_library/higher_e ducation/teac

hers_perceptions_regarding_the_use_of_the_interactive_electronic_whiteboard_in_i nstruction.pdf

Clemens, A. , Moore, T., and Nelson B. (2001). Math Intervention "Smart" Project Student Mathematical Analysis and Reasoning with Technology, Erişim tarihi: 27 Haziran 2016, http://downloads01.smarttech.com/media/sitecore/en/pdf/research_library/k12/math_intervention_smart_project\%20_student_mathematical_analysis_and_reaso ning_with_technology.pdf 
Çelik, H. C. ve Bindak, R. (2005). Illköğretim okullarında görev yapan öğretmenlerin bilgisayara yönelik tutumlarının çeşitli değişkenlere göre incelenmesi. Inönü Üniversitesi Eğitim Fakültesi Dergisi, 6(20), 27-38.

Çelik, H. C. ve Kahyaoğlu, M. (2007). ilköğretim öğretmen adaylarının teknolojiye yönelik tutumlarının kümeleme analizi. Türk Eğitim Bilimleri Dergisi, 5(4), 571-586.

Çelik, S. ve Atak, Ç. (2012). Etkileşimli tahta tutum ölçeğinin geçerlik ve güvenirlik çalışması. Anadolu Journal of Educational Sciences International, 2(2).

Demircioğlu, G. ve Demircioğlu, H. (2015). Öğrencilerin Kimya derslerinde Etkileşimli tahta kullanımına yönelik tutumlarının farklı değişkenler açısından incelenmesi. Eğitim ve Öğretim Araştırmaları Dergisi, 4(2), 387-395.

Erduran, A. ve Tataroğlu, B. (2009). Eğitimde Etkileşimli tahta kullanımına ilişkin fen ve matematik öğretmen görüşlerinin karşılaştırılması. 9th International Educational Technology Conference (IETC2009), 14-21.

Gündüz, S. ve Çelik, H. C. (2015). Öğrencilerin matematik dersinde Etkileşimli tahta kullanımına yönelik tutumlarının çeşitli değişkenler açısından incelenmesi. Dicle Üniversitesi Ziya Gökalp Eğitim Fakültesi Dergisi, 25, 157-174.

Haldane, M. (2007). Interactivity and the digital whiteboard: weaving the fabric of learning. Learning Media andTechnology, 32(3), 257-270.

Hall, J. \& Chamblee, G. (2009). Teacher perceptions of interactive whiteboards: A comparison of users and future-users at high school over a one year period. In I. Gibson, et al. (Eds.), Proceedings of Society for Information Technology \& Teacher Education International Conference 2009, (pp. 1857-1863). Charleston, SC: USA.

Kanatlı, F. ve Schreglman, S. (2012, Haziran). Bilgi teknolojilerinden yararlanma düzeyleri üzerine bir araştırma: Hatay ili örneği. Gümüşhane Üniversitesi Sosyal Bilimler Elektronik Dergisi, 6, 76-85.

Kaya, H. ve Aydın, F. (2011). Sosyal Bilgiler dersindeki coğrafya konularının öğretiminde Etkileşimli tahta uygulamalarına ilişkin öğrenci görüşleri. Zeitschrift für die Welt der Türken Journal of World of Turks, 3(1), 179-189.

Kılınç, S. (2015). Okul öncesi çağındaki çocukların teknoloji kullanımı hakkında ebeveyn görüşlerinin incelenmesi. Yayımlanmamış yüksek lisans tezi, Dumlupınar Üniversitesi Eğitim Bilimleri Enstitüsü, Kütahya.

Milli Eğitim Bakanlığı (2012). Eğitimde FATiH Projesi. Erişim tarihi: 12 Aralık 2015, http://fatihprojesi.meb.gov.tr/tr/icerikincele.php?id=6

Morgan, G. L., (2008). Improving Student Engagement: Use of the Interactive Whiteboard as an Instructional Toll to Improve Engagement and Behavior in the Junior High School Classroom. Unpublished doctoral dissertation, University of Liberty, Virginia.

Muhanna, W. \& Nejem, K. M. (2013). Attitudes of mathematics teachers toward using smart board in teaching mathematics. Contemporary Issues In Education Research - Fourth Quarter 2013, 6(4), 373-380.

Oleksiw, T. (2007). Increasing math test scores with the smart board interactive whiteboard. Erişim tarihi: 30 Aralık 2015, http://downloads01.smarttech.com/media/sitecore/en/pdf/research_library/k- 
12/the_effect_of_the_smart_board_interactive_whiteboard_on_raising_state_test_sco res.pdf

Özdemir, M. (2010, Haziran). Nitel veri analizi: sosyal bilimlerde yöntembilim sorunsalı üzerine bir çalışma. Eskişehir Osmangazi Üniversitesi Sosyal Bilimler Dergisi, 11(1), 323-343.

Painter, D., Whiting, E., Wolters, B. \& Park, D. (2005, 14 Mart). The Use of an Interactive Whiteboard in Promoting Interactive Teaching and Learning. Erişim Tarihi: 12 Aralık 2015, http://gse.gmu.edu/assets/docs/tr/interactive-board_tr.pdf

Robinson, M. (2004). The impact of the interactive electronic whiteboard on student achievement in middle school mathematic. Yayınlanmamış yüksek lisans tezi, Florida State University, USA.

Roennigke, P. \& Carter, S. (2001). Developing self-directed learners and teachers as facilitators with smart board Interactive whiteboard technology. Erişim Tarihi: 31 Aralık 2015, http://downloads01.smarttech.com/media/sitecore/en/pdf/research_library/k12/developing_selfdirected_learners_and_teachers_as_facilitators_with_smart_board_interactive_whiteb oard_technology.pdf

Sevindik, T. ve Gürol, M. (2009). The effects of smart classrooms on the high education students' attitudes, E-Journal of New World Sciences Academy, 4(4), 612-628.

Seyitoğlu, E. (2014, Ocak). Etkileşimli tahta kullanılan matematik dersinden yansımalar.

Yayımlanmamış yüksek lisans tezi, Karadeniz Teknik Üniversitesi Eğitim Bilimleri Enstitüsü, Trabzon.

Smith, F., Hardman, F. \& Higgins, S. (2006). The impact of interactive whiteboards on teacherpupil interaction in the national literacy and numeracy strategies. British Educational Research Journal, 32(3), 443-457.

Solvie, P. (2004). The digital whiteboard: a tool in early literacy instruction. International Reading Association, 57(5), 484-487.

Tataroğlu, B. ve Erduran, A. (2010). Matematik dersinde Etkileşimli tahtaya yönelik tutum ölçeğinin geliştirilmesi. Turkish Journal of Computer and Mathematics Education, 3, 233250.

Tate, L. (2002). Using the interactive whiteboard to increase student retention, attention, participation, interestand success in a required general education college course. Erişim Tarihi: 28 Haziran 2016, http://downloads01.smarttech.com/media/sitecore/en/pdf/research_library/higher_ed ucation/usin g_the_interactive_whiteboard.pdf?WT.qs_osrc=ASK-166960010

Temelli, D. ve Genç, S. Z. (2014). Etkileşimli tahtaya yönelik öğretmen tutumları (Çanakkale ili örneği). Pegem Eğitim ve Öğretim Dergisi, 4(4), 41-58.

Türel, Y. K. \& Johnson, T. E. (2012). Teachers' belief and use of interactive whiteboards for teaching and learning. Educational Technology \& Society, 15(1), 381-394.

Türkoğlu, T. (2014). Fen ve teknoloji öğretiminde Etkileşimli tahta kullanımının 6. Sınıf öğrencilerinin akademik başarı, tutum ve görüşleri üzerine etkileri. Yayımlanmamış yüksek lisans tezi, Celal Bayar Üniversitesi Fen Bilimleri Enstitüsü, Manisa. 
Wall, K., Higgins, S., \& Smith, H. (2005). The visual helps me understand the complicated things': pupil views of teaching and learning with interactive whiteboards. British Journal of Eductional Technology, 36 (5), 851-867.

Winkler, R. L. (2011). Investigating the Impact of Interactive Whiteoard Professional Development on Lesson Planning and Student Math Achievement. Unpublished doctoral dissertation, University of Liberty, USA.

Yıldırım, A. ve Şimşek, H. (2013). Sosyal bilimlerde nitel araştırma yöntemleri (Genişletilmiş dokuzuncu baskı). Ankara: Seçkin Yayıncılık.

Yıldızhan, Y. H. (2013). Temel eğitimde Etkileşimli tahtanın matematik başarısına etkisi. Middle Eastern \& African Journal of Educational Research, 5, 110-121.

Zengin, F. K., Kırılmazkaya, G. ve Keçeci, G. (2011). Etkileşimli tahta kullanımının ilköğretim ögrencilerinin Fen ve Teknoloji dersindeki başarı ve tutuma etkisi. 5th International Computer \& Instructional Technologies Symposium. Firat University, Elazığ. 


\section{SUMMARY}

Advances in technology, information and communication led to changes in teaching methods and bring new understanding and education along with the use of vehicles. In the information age we live in computers, multimedia, audio, images, animation, concepts and technologies such as the Internet and developing web technologies are being used in education and training (Alakoç, 2003; Akt. Türkoğlu, 2004). Use of smart boards with these features helps developing problem solving, creativity and the ability to cooperate with each other. Smart board: because of having features such as visualizing concepts, ensuring integrity and permanence, encouraging learning, motivation and ensure efficiency, versatile and easy to use, interaction; The use in an educational environment contributes to the teaching-learning process and is one of the most effective technology that can be used in educational settings (Painter, Whiting, Wolters \& Park, 2005). Smart boards, has led students to be excited and enthusiastic to participate in courses and smart boards', increasing the motivation of smart boards, in promoting the course and was regarded as an effective tool to understand the subject (Oleksiw, 2007). It is important how the students' admitting these smart boards' features, equality of opportunity which is aimed with FATiH project, and improving technology movement. So, this work's purpose is to examine secondary school students' views about using interactive boards in education. In this work quantitative and qualitative research methods (mixed) were used. In the qualitative part; students' opinions were compiled in the form of developed semi-structured with open-ended questions. Working group of the Research, was created by 225 secondary school student who continue education and teaching in state school $113(\% 50,2)$ female, $112(\% 49,8)$ male. As getting data tool; personal information form which is developed by researchers and obtained research group students' demographic data and interactive board attitude scale which was developed by Celik and Atak was used. In addition, for the collection of qualitative data The open-ended 7 research questions developed by researchers was transformed into structured form. the form which was revised in control of 4 specialists and 1 language experts total 5 experts was finalized in the last form as 6 open ended question.

The results arising from the research findings derived from quantitative data; as seen in the table significance level for ${ }^{*} p<.05$. is $674>.05$ and result isn't significant. In other words, the secondary school students' attitudes towards interactive board does not show a significant difference according to gender. Secondary school student's in the interactive whiteboard attitude, total scores they receive from the scale, there are significant differences according to the class that they study $[F(3-221)=5,990$, $p<.05]$. In result of LSD test which was done with aim of determining differences it showed that differences are between 5th grade and 6 th grade, 7 th grade and 8 th grade, 6 th grade and 5 th grade, 7 th grade and 5 th grade, 8 th grade and 5 th grade. table 3 . As seen in the table 4 significance level for ${ }^{*} p<.05$ is $929>.05$.and result isn't significant. In other words, the Secondary school students' attitudes towards interactive board does not show a significant difference according to having a computer. (table 4). Secondary school students' total scores which they received from the scale the interactive whiteboard attitude there is no significant difference compared to the weekly internet usage time [F(4$220)=, 637, p>05]$. Secondary students' attitudes towards interactive board does not change according to the weekly internet usage time (Table 5). Secondary school students' total scores which they received from the scale the interactive whiteboard attitude there is no significant difference compared to having mobile device $F(5-219)=1,448, p>05$ ] (Table 6).

Secondary school students' attitudes toward the interactive board does not change according to the time of the having mobile device. Secondary school students' total scores which they received from the scale the interactive whiteboard attitude there is significant difference compared to the using mobile device $[F(2-222)=12,145, p<05]$. in result of LSD test which was done with aim of determining differences it showed that the difference is between for 0-2 years and more than 4 years; for 2-4 years and more than 4 years; more than 4 years and 0-2 years and between 2-4 years (Table 7). The study of the results of the findings of qualitative data; to Secondary school students, "Is it an advantage to use the smart board lessons?" question was asked. Answers given by students are grouped in 3 categories. These categories has been identified as Use of Technology, Contact and Impact. "How affect Smart board use your motivation about course? " Question was asked. Student responses are gathered under one category. This category has emerged as motivation. As the theme of intense attention $n=9$ was determined in this category. "The use of interactive whiteboard classroom environment interactions 
affect your course and in what direction?" Question was asked. Student responses are gathered under 2 categories. These categories have emerged as communication and influence. To secondary school students "What do you like or dislike with using smart board in your lesson? Question was asked. Answers given by students are grouped in three categories. These three categories was determined as Technology Use, Infrastructure and Health. Secondary School Students "in which suggestions for making more effective use of interactive whiteboards in class you can find " The question was asked. . Student responses are gathered under 2 categories. To Secondary School Students "if you did a comparison between traditional methods and smart board use, which would you prefer? Why? "Question was asked. Student responses are gathered under 3 categories. Starting from the research results by observing secondary school students' developing process, determining deficiencies, Making educational planning in order to eliminate these deficiencies and increasing the students' knowledge and skills in order to increase the contribution in the process of integration of information and communication technologies are important. 